Fakultas Hukum, Universitas Lampung, Bandar Lampung, Lampung, Indonesia. http:/ /jurnal.fh.unila.ac.id/index.php/corruptio

Volume 02 Issue 1, January-June 2021. PP: 13-22

P-ISSN: 2723-2573 E-ISSN: 2745-9276

\title{
The Funcitonalization of in Absentia Court as a Form of Corruption Crime's Asset Recovery
}

\author{
Raffky Ariansyah \\ raffky.ariansyah@gmail.com
}

Bank Pembangunan Daerah, Indonesia.

Sunarto

sunarto@fh.unila.ac.id

Universitas Lampung, Indonesia

Sanusi Husin

sanusi.husin@fh.unila.ac.id

Universitas Lampung, Indonesia.

Dwi Nurahman

dwi.nurahman1003@students.unila.ac.id

Universitas Lampung, Indonesia.

Submitted: 21 January 2021; Reviewed: 05 February 2021; Accepted: 26 April 2021

\begin{tabular}{ll}
\hline \hline Article's Information & \multicolumn{1}{c}{ Abstract } \\
\hline Keywords: Funcitonalization; Absentia; & $\begin{array}{l}\text { Examination of corruption cases in the } \\
\text { absence of the defendant at trial still has } \\
\text { Form; Corruption; Asset. }\end{array}$ \\
DOI: & $\begin{array}{l}\text { Number } 31 \text { of } 1999 \text { as amended in Law } \\
\text { Number } 20 \text { of } 2001 \text { concerning } \\
\text { https://doi.org/10.25041/corruptio.v2il.2257 } \\
\text { eradicating criminal acts of corruption, } \\
\text { especially in Article 38, provides an } \\
\text { opening for the judiciary in absentia as } \\
\text { an orientation to save state assets. What } \\
\text { is the importance of the judiciary in } \\
\text { absentia as an effort to recover assets, } \\
\text { how is the implementation of justice in } \\
\text { absentia to recover assets? What is the } \\
\text { basis for the judges' legal considerations } \\
\text { on the implementation of the trial? Then }\end{array}$ \\
\hline \hline
\end{tabular}


this study uses a normative research method with a normative juridical approach, while this type of research is descriptive. Based on the discussion in the study that the importance of the in absentia judiciary as an effort to recover assets carried out by the defendant legally and appropriately summoned to eradicate the crime of corruption and recover state losses can still be implemented, the assets and all assets of the defendant based on the verdict are proven to be related to corruption. A criminal act of corruption can then be executed. The implementation of the judiciary in absentia is an effort to recover assets through a legal process by taking into account the defendant's rights. The judiciary without the presence of the defendant is guided by Law Number 31 of 1999 as amended in Law Number 20 of 2001 concerning the eradication of criminal acts of corruption in Article 38 paragraph (1). The basis for the Judge's legal considerations regarding the trial examination in the defendant's absence is to ensure legal certainty so that the prosecutor as the executor can save the country's assets with considerations of exceptionality, return, and rescue of state assets.

\section{A. Introduction}

Law Number 20 of 2001 concerning the Crime of Corruption (Anti-Corruption Law) contains various regulations oriented towards restoring the country's economy, which is a material aspect, and eradicating criminal acts of corruption that occur in Indonesia. ${ }^{1}$ Corruption cases have become a massive problem in Indonesia and have even become a worldwide crime. ${ }^{2}$ Corruption can be categorized as a transnational organized crime because people involved in criminal acts of corruption have their respective functions, roles, and duties, so it is not easy to be exposed, acted upon, and eradicated by law enforcers. ${ }^{3}$ At that time, the framework of law enforcement was no longer limited to pursuing the perpetrator but

\footnotetext{
${ }^{1}$ Ismail Rumadan, "PENAFSIRAN HAKIM TERHADAP KETENTUAN PIDANA MINIMUM KHUSUS DALAM UNDANG-UNDANG TINDAK PIDANA KORUPSI,” Jurnal Hukum Dan Peradilan 2, no. 3 (April 23, 2018): 379, https://doi.org/10.25216/jhp.2.3.2013.379-404.

2 Lulu Mufidah, "NON-CONVICTION BASED ASSET FORFEITURE SEBAGAI UPAYA PENGEMBALIAN KERUGIAN NEGARA AKIBAT TINDAK PIDANA KORUPSI,” Jurnal Kertha Semaya 9, no. 2 (January 4, 2021): 235-49, https://doi.org/10.24843/KS.2021.v09.i02.p05.

${ }^{3}$ Refki Saputra, "Tantangan Penerapan Perampasan Aset Tanpa Tuntutan Pidana (Non-Conviction Based Asset Forfeiture) Dalam RUU Perampasan Aset Di Indonesia,” Jurnal Integritas Volume 3. Nomor 1, Maret 2017 , accessed January 20, 2021, https://jurnal.kpk.go.id/index.php/integritas/article/view/158/40.
} 
also through the pursuit of illegal profits. So that law enforcement officers are relatively incapable of dealing with this crime, especially regarding the confiscation of assets and the return of state losses due to corruption, which reduces the possibility of them being reported or prosecuted. For example, the Philippines, which is to return assets alone, took 18 years to withdraw funds amounting to USD 624 million from the diversion of state funds by former President Ferdinand Marcos at a Switzerland bank. In Ferdinand Marcos's case in 1986, the Philippine government has formed a particular institution to restore assets that have been corrupted by Marcos, namely The Presidential Commission on Good Governance (PCGG).

This includes, in addition to criminal threats, heavier punishments with an orientation to give a deterrent effect to corruptors, such as imposing criminal sanctions in the form of imprisonment and fines according to the assets corrupted by the perpetrator of the corruption crime. The formulation of an anti-corruption law is based on returning state assets that corruptors have corrupted. The Corruption Act's urgency is a legal breakthrough to carry out an examination process at the trial level in the corruption court environment. However, the defendant is not present (known as the in absentia trial). This provision is contained in the Corruption Act, which is regulated in Article 38 paragraph (1) "If the defendant has been legally summoned, and is not present at court without a valid reason, the case can be examined and decided without his presence". Referring to the substance's explanation, the main objective of the trial is to save state assets. Judges can decide cases without the presence of the defendant. The favorable implication is that legal certainty guarantees and assets resulting from corruption are confiscated and executed. ${ }^{4}$

This method is extraordinary, namely by examining the criminal act of corruption without the defendant's presence (in absentia). ${ }^{5}$ This in absentia trial was mandated by Article 38 Paragraph (1) of Law Number 20 of 2001. However, this principle's negative impact is against the Criminal Procedure Code or known as KUHAP, which adheres to the presence of the defendant's principle. According to Andi Hamzah, the examination in court is carried out by the Judge directly, which means directly to the accused and the witnesses. ${ }^{6}$ So the principle of the presence of the defendant in a corruption case begins with the human rights of the defendant. In contrast, a human being has the right to defend himself and defend his rights, freedom, property, or honor. ${ }^{7}$ Based on the explanation above, the settlement of a criminal act should have presented the defendant, but in court in absentia requires the settlement of cases where corruption, terrorism, and money laundering can be carried out even in the absence of the defendant. ${ }^{8}$ However, the in absentia trial is not entirely under other provisions. The in absentia trial is carried out because it avoids things that hinder the process of resolving a case carried out by the perpetrators of criminal acts who have the intention of escaping from criminal charges because, for example, pretending to be ill or undergoing medical errands abroad, especially countries that have not entered into extradition agreements with the

\footnotetext{
${ }^{4}$ Ricardo Santos and Hery Firmansyah, "PROSEDUR PELAKSANAAN MUTUAL LEGAL ASSISTANCE TERHADAP PEMULIHAN ASET HASIL KORUPSI YANG DILARIKAN KE LUAR NEGERI (PROCEDURES FOR THE IMPLEMENTATION OF MUTUAL LEGAL ASSISTANCE TO RECOVER ASSETS RESULTING FROM CORRUPTION THAT ARE RUSHED ABROAD)," Jurnal Hukum Lex Generalis, vol. 2 (Bulan Kesatu, January 31, 2021), https://jhlg.rewangrencang.com/.

5 Suriady Harianja, "Peradilan In Absentia Pada Perkara Tindak Pidana Korupsi Dalam Perspektif HAM Terdakwa," Unnes Law Journal 2, no. 1 (April 30, 2013): 36-43, https://doi.org/10.15294/ULJ.V2I1.2903.

${ }^{6}$ Bastianto Nugroho, "PERANAN ALAT BUKTI DALAM PERKARA PIDANA DALAM PUTUSAN HAKIM MENURUT KUHAP,” accessed February 8, 2021, https://doi.org/10.20473/ydk.v32i1.4780.

${ }^{7}$ I Nyoman Agus Trisnadiasa. et al., " Pemeriksaaan Dan Putusan Tanpa Kehadiran Terdakwa Tindak Pidana Korupsi Dalam Pengadilan Kaitannya Dengan Hak Asasi Terdakwa,” Jurnal Hukum Saraswati (JHS), vol. 2, March 1, 2020, https://ojs.unud.ac.id/index.php/kerthawicara.

8 Menurut Kuhap, Oleh: Arly, and Y Mangoli, "EKSISTENSI PERADILAN IN ABSENTIA DALAM HUKUM ACARA PIDANA DI INDONESIA,” LEX CRIMEN, vol. 5, April 7, 2016, https://ejournal.unsrat.ac.id/index.php/lexcrimen/article/view/11682.
} 
Indonesian state. Therefore, the defendant's presence in a trial is needed to carry out the imposition of a sentence or sanction of corruption.

The defendant's obligation to be present at criminal proceedings is regulated in Article 1, number 15, Article 189 paragraph (1) of the Criminal Procedure Code and Article 12 paragraph (1) of Law Number 48 of 2009 concerning Judicial Powers. That is why the provisions stipulated in the law on corruption eradication are special or are often understood by the principle of lex specialist derogate lege general, which means that the Criminal Procedure Code is a general procedural law provision disregarded by the existence of this law. Thus, the absence of a defendant has been summoned legally or adequately following the prevailing laws and regulations.

The social fact as a legal issue is that the in absentia judiciary has been implemented since 2002. Until now, there have been cases of corruption that have been implemented in a way that has been investigated and decided in the absence of a defendant, one of which is the case that was examined and decided in court in absentia was also carried out by Corruption Court Class I A Tanjung Karang, namely Case Number 46/Pid.Sus-TPK/2016/PN.Tjk in the main corruption case with the defendant Abdul Mukti (DPO) in a criminal case of corruption in SMA Negeri 6 Metro City's construction project. The defendant was sentenced to 3 (three) years in prison. Referring to the legal issue described in the main issue above, this research's crucial issue is why the importance of justice in absentia, the implementation of the judiciary, and the things that become the basis for judges for legal considerations in making decisions. The research method is a normative method with a normative juridical approach. A normative juridical approach is an approach based on the primary legal materials by examining theories, concepts, legal principles, and legislation related to this research. In its execution, the research uses primary data and secondary data. Primary data used are direct observation and secondary data using journals related to criminal acts of corruption, Law Number 31 of 1999 concerning Corruption Eradication, the Criminal Code, and the Criminal Procedure Code.

\section{B. Discussion}

\section{The Importance of In absentia Judiciary As Asset Recovery Efforts}

The judiciary's important thing in absentia as this meaning is made clear in the Corruption Act, namely saving and returning state assets. Conceptionally, what is meant in the Corruption Act mandate is identical to asset recovery for all forms of state finances. As is well known, the main element of corruption is a loss to the state. Important things for the implementation of the judiciary in absentia are as follows:

(1) Executor's faster execution of assets from corruption is legally confiscated and entered into the state treasury after a court ruling.

(2) Decisions as legal products of judges serve as guidelines and sources of law for recovering losses suffered by the state by implementing procedures that are applied following matters stipulated in statutory regulations. The form of recovering state financial losses is more factual without any resistance or lawsuits from any party.

Corruption cases where the investigation results have found sufficient evidence and confiscation has been carried out to recover state financial losses, even though there are no reports of the Suspects' Investigation. Regarding examining a corruption case, each court gives a different decision: some accept the trial in absentia for defendants who have not been examined at the level of investigation, and some refuse because there is no law of procedure. ${ }^{9}$ This became a weakness and became a reference material to undermine the non-acceptance of

\footnotetext{
9 Zul Akli, "Peradilan In Absentia Terhadap Terdakwa Yang Belum Di-Periksa Pada Tingkat Penyidikan Dalam Perkara Tindak Pi-Dana Korupsi," REUSAM- Jurnal Ilmu Hukum, vol. 8, May 13, 2020, https://ojs.unimal.ac.id/index.php/reusam/article/view/2613.
} 
a verdict in the absence of the defendant. However, in the handling of the prevention and eradication of the criminal act of corruption, elements have been regulated to be examined and decided in absentia (without the presence of the defendant), that is, the defendant has been summoned legally or adequately and is not present at the trial without any valid reason and unknown of existence.

Ordinary and extraordinary legal remedies in criminal decisions that have obtained permanent legal force (inkracht van gewijsde) are extraordinary legal remedies as regulated in Chapter XVII of Law No. 8 of 1981 concerning Criminal Procedure Law (hereinafter referred to as KUHAP $^{10}$ ) and Law No. 14 of 1985 concerning the Supreme Court (hereinafter referred to as the Supreme Court Law). ${ }^{11}$ In carrying out asset recovery, of course, look at the development of corruption in quality and quantity. After examining it in-depth, it is not an exaggeration to say that corruption is not an ordinary crime but is pronounced as an extraordinary crime. ${ }^{12}$

Based on this, the importance of the judiciary in absentia as an effort to recover as an effort to return state assets resulting from corruption is still difficult for the Indonesian people to reach, so that disclosure efforts must be considered in success. According to the author, the weakness of the judiciary in absentia is the possibility that the difference in the testimony of the witnesses, the difference in the amount of evidence confiscated is insufficient to compensate for state losses, the data (investigation results) are not real or one-sided. Simultaneously, the material crimes are concrete. The Judge cannot clarify the defendant because the unilateral evidence results in the Judge's difficulty getting a conviction. According to the author, considering that the criminal act of corruption is a great crime, handling and prevention are necessary with extraordinary efforts as well because the consequences of this dishonorable act can damage the joints of the life of the nation and state. The return of state assets at present there is still many state assets that law enforcement officials have not detected, given that the return of state finances resulting from corruption can lead to various acts of corruption, such as the accumulation of wealth resulting from corruption in several regions or other means by perpetrators. to be able to transfer assets and many of which are still unknown. ${ }^{13}$

\section{Implementation of In absentia Trial as an Asset Recovery}

The theory of proof in criminal procedural law is the guide for judges in conducting trials in court. ${ }^{14}$ Following time, the system of proof in criminal procedural law trials in Indonesia has changed. The legal problems that occurred in the criminal justice process for the crime of corruption, the suspect are not known, even though he has been summoned according to the procedural law process. If confiscation is associated with confiscation as an

\footnotetext{
${ }^{10}$ Short for Kitab Hukum Acara Pidana

${ }^{11}$ Adi Purnomo Santoso, "PERMOHONAN PENINJAUAN KEMBALI AHLI WARIS TERPIDANA SECARA IN ABSENTIA DALAM PERKARA TINDAK PIDANA KORUPSI (Studi Kasus Putusan MA NOMOR 97 PK / PIDSUS / 2012)," Ilmu Dan Budaya 41, no. 58 (October 23, 2018), http://journal.unas.ac.id/ilmubudaya/article/view/444.

${ }^{12}$ Ade Kosasi, "Studi Komparasi Pengembalian Aset Negara Hasil KorupsiMenurut Konvensi Anti Korupsi 2003 Dan Undang-Undang TipikorComparative Study Of The Returning Corrupted State Assets According To The 2003 Anti-Corruption Convention And Corruption Law," SURYA KEADILAN Muhammadiyah Bengkulu, Universitas 2, no. 2 (2018), www.detiknews.com.

${ }^{13}$ Abd Razak Musahib, "PENGEMBALIAN KEUANGAN NEGARA HASIL TINDAK PIDANA KORUPSI," Katalogis, vol. 3 (Tadulako University, 2015).

${ }^{14}$ Haklainul Dunggio, Bambang Sugiri, and Rachmad Syafa'at, "PERADILAN IN ABSENTIA BAGI PELANGGAR LALU LINTAS YANG BERKEADILAN THE JUSTICE OF IN ABSENTIA JUDICATORY FOR TRAFFIC OFFENDER,” Jurnal Ilmiah Pendidikan Pancasila Dan Kewarganegaraan, vol. 4, January 6, 2020, http://journal2.um.ac.id/index.php/jppk.
} 
additional crime, then Article 38 of Law 31 of 1999 on Corruption Eradication explains that confiscating confiscation is only to the convict's property obtained due to a crime or property of the convict who has deliberately used to commit crimes. ${ }^{15}$

In practice, the trial in absentia also refers to the Criminal Procedure Code and the AntiCorruption Law, especially the subject of a legal summoning procedure according to procedural law. The accused who was not examined at trial has been put forward, further proven as valid and objective reasons. The purpose of a trial in absentia is to save state finances, whether those that have been corrupted or those that are still suspected of having something to do with criminal cases of corruption, both those that have been confiscated and those that have not been abused to be confiscated for the state through a court decision, then, of course, this goal different from the trial in absentia in cases of other criminal acts. ${ }^{16}$ Judiciary in absentia in cases of criminal acts of corruption can effectively save state assets if the assets belonging to the defendant, which are the result of a criminal act of corruption, have been confiscated. So that after a judge's decision, these assets can be executed immediately. However, on the other hand, the in absentia court becomes ineffective if the assets belonging to the defendant can be confiscated because the main objective of the in absentia court in cases of corruption is saving state assets.

Thus a trial in absentia can be carried out if it meets the criteria for illegitimate reasons. Namely, the defendant is not known, or his whereabouts are unknown. The defendant's existence is specific and clear. However, the defendant cannot be presented at the trial due to specific legal reasons, and the defendant's identity is fully known, but its whereabouts are unknown. In this case, the laws and regulations justify if the judiciary or trial in absentia is applied to break the impasse in examining the accused at trial. But a defense cannot be made in the absentia court because the defendant does not appear legally, so the defendant does not use his rights to defend himself. In other words, the trial is absentia without the defense of the defendant. In practice in Indonesia, the judiciary in absentia already has a decision from the judges' panel, namely in Court Decision Number 06/PID.SU/TIPIKOR/2013/PN.PL, where the judges at the Palu District Court explained that the defendant had been appropriately summoned and was not present at court trial without a valid reason. That the defendant has been legally proven to have committed the criminal act of corruption as stated in the subsidiary indictment.

\section{Legal Ground Considerations of Judges}

The grounds for the Judge's consideration of the in absentia decision is applied to the accused of a criminal act of corruption following the concept of criminal procedure law with reasons.

a. Consideration of Article 38 of the Corruption Act, namely if the defendant is still absent without giving a valid reason according to the law, then an In absentia examination can still be carried out;

b. Consideration of the nature of procedures that have been excluded or known as exclusion because corruption is a form of extraordinary criminal action, so it is necessary to solve it, which must also be done with extraordinary methods of handling it.

c. Considerations for recovering state losses.

\footnotetext{
15 Muhammad Dzakir and Gusti Mahardika, "Tinjauan Penerapan Sita Jaminan (Conservatoir Beslag) Dalam Tindak Pidana Korupsi,” accessed January 20, 2021, https://doi.org/10.20473/jd.v3i2.18201.

16 Al Masyhur, "Pelaksanaan Peradilan In Absentia Dalam Penanganan Tindak Pidana Korupsi Dikaitkan Dengan Hak Asasi Manusia (HAM)," Perspektif Hukum, accessed January 20, 2021, http://perspektifhukum.hangtuah.ac.id/index.php/perspektif/article/view/296/204.
} 
d. Considerations for the principle of legal certainty and the principle of speedy justice in the prosecutor's execution process.

Furthermore, other primary considerations are

1) Based on the Decision of the Chief Judge of the Panel of Judges, the trial in a quo case, which was conducted through the absence of the presence of the Defendants by adhering to the summoning procedure, was following the SOP and procedural law adequately carried out by the executor. The Public Prosecutor also referred to the order of the Panel of Judges by calling via newspaper and electronic media, but the defendant still did not exercise his right to be present at the trial;

2) A form of consideration is also the Government Program to eradicate corruption. The fact that has happened in the field is that there are obstacles due to various obstacles. It is challenging to present the convicted corruptor. Meanwhile, most of the perpetrators fled abroad with their corruption. Meanwhile, the defendant caused a large number of losses to the state, and it was not sure to return to the country of origin;

\section{Conclusion}

Based on the explanation above, the conclusion can be drawn that the importance of the judiciary in absentia as asset recovery is that when the defendant has been properly summoned to court to eradicate the crime of corruption and the return of state losses can still be carried out, the defendant's assets or assets are executed. The judiciary's implementation in absentia is carried out based on the procedural law in force in Indonesia. The basis for the Judge's legal considerations for the in absentia court is that there is legal certainty. The executing prosecutors can immediately execute to return the country's assets with considerations of excellence, return, and rescue of state assets.

\section{Bibliography}

\section{A. Book}

Hartati, Evi, Tindak Pidana Korupsi, Jakarta: Sinar Grafika, Jakarta. 2008.

Hamzah, Andi, Hukum Pidana dan Acara Pidana, Jakarta: Ghalia Indonesia. 2006.

Nawawi Arief, Barda, Bunga Rampai Kebijakan Hukum Pidana, Bandung: Citra Aditya Bakti. 2012.

Rukmini, Mien, Perlindungan HAM melalui Asas Praduga Tak Bersalah dan Asas Persamaan Kedudukan dalam Hukum pada Peradilan Pidana Indonesia, Bandung: PT Alumni. 2007.

Soekanto, Soerjono, Hengki Liklikuwata, dan Mulyana W. Kusumah. Kriminologi Suatu Pengantar, Jakarta: Ghalia Indonesia. 1981.

Soemitro, Ronny Hanitijo. Metodologi Penelitian Hukum dan Yurimetri, Jakarta: Ghalia Indonesia. 2011.

\section{B. Journal}

Akli, Zul. "Peradilan In Absentia Terhadap Terdakwa Yang Belum Di-Periksa Pada Tingkat Penyidikan Dalam Perkara Tindak Pi-Dana Korupsi." REUSAM- Jurnal Ilmu Hukum. Vol. 8, May 13, 2020. https://ojs.unimal.ac.id/index.php/reusam/article/view/2613.

Dunggio, Haklainul, Bambang Sugiri, and Rachmad Syafa'at. "PERADILAN IN ABSENTIA BAGI PELANGGAR LALU LINTAS YANG BERKEADILAN THE JUSTICE OF IN ABSENTIA JUDICATORY FOR TRAFFIC OFFENDER." Jurnal Ilmiah Pendidikan Pancasila Dan Kewarganegaraan. Vol. 4, January 6, 2020. http://journal2.um.ac.id/index.php/jppk. 
Dzakir, Muhammad, and Gusti Mahardika. "Tinjauan Penerapan Sita Jaminan (Conservatoir Beslag) Dalam Tindak Pidana Korupsi.” Accessed January 20, 2021. https://doi.org/10.20473/jd.v3i2.18201.

Harianja, Suriady. "Peradilan In Absentia Pada Perkara Tindak Pidana Korupsi Dalam Perspektif HAM Terdakwa." Unnes Law Journal 2, no. 1 (April 30, 2013): 36-43. https://doi.org/10.15294/ULJ.V2I1.2903.

I Nyoman Agus Trisnadiasa., Ni Komang Ratih Kumala Dewi, JagadithaLaw Office, and Fakultas Hukum Universitas Mahasaraswati Denpasar. “Pemeriksaaan Dan Putusan Tanpa Kehadiran Terdakwa Tindak Pidana Korupsi Dalam Pengadilan Kaitannya Dengan Hak Asasi Terdakwa." Jurnal Hukum Saraswati (JHS). Vol. 2, March 1, 2020. https://ojs.unud.ac.id/index.php/kerthawicara.

Kosasi, Ade. "Studi Komparasi Pengembalian Aset Negara Hasil KorupsiMenurut Konvensi Anti Korupsi 2003 Dan Undang-Undang TipikorComparative Study Of The Returning Corrupted State Assets According To The 2003 Anti-Corruption Convention And Corruption Law." SURYA KEADILAN Muhammadiyah Bengkulu, Universitas 2, no. 2 (2018). https://core.ac.uk/reader/228779730.

Kuhap, Menurut, Oleh : Arly, and Y Mangoli. "EKSISTENSI PERADILAN IN ABSENTIA DALAM HUKUM ACARA PIDANA DI INDONESIA." LEX CRIMEN. Vol. 5, April 7, 2016. https://ejournal.unsrat.ac.id/index.php/lexcrimen/article/view/11682.

Masyhur, Al. "Pelaksanaan Peradilan In Absentia Dalam Penanganan Tindak Pidana Korupsi Dikaitkan Dengan Hak Asasi Manusia (HAM) ."Perspektif Hukum. Accessed January 2021 hukum.hangtuah.ac.id/index.php/perspektif/article/view/296/204.

http://perspektif-

Mufidah, Lulu. "NON-CONVICTION BASED ASSET FORFEITURE SEBAGAI UPAYA PENGEMBALIAN KERUGIAN NEGARA AKIBAT TINDAK PIDANA KORUPSI." Jurnal Kertha Semaya 9, no. 2 (January 4, 2021): 235-49. https://doi.org/10.24843/KS.2021.v09.i02.p05.

Musahib, Abd Razak. "PENGEMBALIAN KEUANGAN NEGARA HASIL TINDAK PIDANA KORUPSI." Katalogis. Vol. 3. Tadulako University, 2015.

Nugroho, Bastianto. "PERANAN ALAT BUKTI DALAM PERKARA PIDANA DALAM PUTUSAN HAKIM MENURUT KUHAP." Accessed February 8, 2021. https://doi.org/10.20473/ydk.v32i1.4780.

Refki Saputra. "Tantangan Penerapan Perampasan Aset Tanpa Tuntutan Pidana (NonConviction Based Asset Forfeiture) Dalam RUU Perampasan Aset Di Indonesia." Jurnal Integritas Volume 3. Nomor 1, Maret 2017. Accessed January 20, 2021. https://jurnal.kpk.go.id/index.php/integritas/article/view/158/40.

Rumadan, Ismail. "PENAFSIRAN HAKIM TERHADAP KETENTUAN PIDANA MINIMUM KHUSUS DALAM UNDANG-UNDANG TINDAK PIDANA KORUPSI." Jurnal Hukum Dan Peradilan 2, no. 3 (April 23, 2018): 379. https://doi.org/10.25216/jhp.2.3.2013.379-404.

Santos, Ricardo, and Hery Firmansyah. "PROSEDUR PELAKSANAAN MUTUAL LEGAL ASSISTANCE TERHADAP PEMULIHAN ASET HASIL KORUPSI YANG DILARIKAN KE LUAR NEGERI (PROCEDURES FOR THE IMPLEMENTATION OF MUTUAL LEGAL ASSISTANCE TO RECOVER ASSETS RESULTING FROM CORRUPTION THAT ARE RUSHED ABROAD)." Jurnal Hukum Lex Generalis. Vol. 2. Bulan Kesatu, January 31, 2021. https://jhlg.rewangrencang.com/.

Santoso, Adi Purnomo. "PERMOHONAN PENINJAUAN KEMBALI AHLI WARIS TERPIDANA SECARA IN ABSENTIA DALAM PERKARA TINDAK PIDANA KORUPSI (Studi Kasus Putusan MA NOMOR 97 PK / PIDSUS / 2012).” Ilmu Dan Budaya 41, no. 58 (October 23, 2018). http://journal.unas.ac.id/ilmu- 
budaya/article/view/444.

\section{Regulation}

Law Number 8 of 1981 concerning Criminal Procedure Law (KUHAP).

Law Number 31 of 1999 in conjunction with Law Number 20 of 2001 concerning Eradication of Corruption. 
